\title{
Hormigones con cementos compuestos ternarios. Parte I: estado fresco y resistencia mecánica
}

\author{
Ternary blended cement concrete. \\ Part I: early age properties and mechanical strength
}

\author{
G. Menéndez(*), V. L. Bonavetti ${ }^{*}$ y E. F. Irassar ${ }^{(*)}$
}

Recepción/Received: 20-X-05

Aceptación/Accepted: 3-V-06

\section{RESUMEN}

En la bibliografía existe abundante información acerca del comportamiento mecánico y durable de hormigones elaborados con la incorporación individual de caliza y de escoria granulada de alto horno. Sin embargo, la modificación de las propiedades por la acción conjunta de las mismas es prácticamente desconocida. En este trabajo se evalúan las propiedades en estado fresco y el comportamiento mecánico de hormigones elaborados con cementos compuestos binarios y ternarios conteniendo hasta $18 \%$ de caliza y $20 \%$ de escoria granulada de alto horno. Los resultados indican que la utilización de cementos ternarios en hormigones no modifican sustancialmente el tiempo de fraguado, disminuyen la exudación y presentan un mejor comportamiento mecánico que los hormigones elaborados con cemento Portland sin adición y/o binarios.

Palabras clave: cementos compuestos ternarios, caliza, escoria granulada de alto horno, modelización, resistencias mécanicas.

\section{SUMMARY}

While there is ample information in the literature on the mechanical performance and durability of concrete made with either limestone or granulated blast furnace slag, very little is known about the effect of the combined action of these two additions on concrete properties. The present paper evaluates the early stage properties and mechanical strength of binary and ternary cement concrete containing up to $18 \%$ limestone and $20 \%$ granulated blast furnace slag. The results show that the use of ternary cements has no substantial effect on concrete setting time, although it does reduce bleeding and enhance mechanical strength with respect to unadditioned Portland and/or binary cement concrete.

Keywords: ternary blended cements, limestone, granulated blast furnace slag, prediction model, mechanical strength.

\section{INTRODUCCIÓN}

El uso de adiciones minerales contribuye al desarrollo sostenible de la industria del cemento y del hormigón, su empleo implica una disminución de la erosión y la deforestación del suelo, una reducción del uso de recursos

\section{INTRODUCTION}

The use of mineral additions contributes to the sustainability of the cement and concrete industries, for the reduction in soil erosion and deforestation, exploitation of natural resources (raw materials and fuel) and greenhouse gas

(*) Departamento de Ingeniería Civil. Facultad de Ingeniería, Universidad Nacional del Centro (B7400J WI), Olavarría (Argentina). 
naturales (materias primas y combustibles) y una menor emisión de gases que favorecen el efecto invernadero. Consecuentemente, el reemplazo de cemento por adiciones constituye no sólo una solución adecuada a algunos problemas de índole tecnológicos, sino también a cuestiones económicas y de protección del medio ambiente.

El empleo de caliza como reemplazo parcial del clínker produce un efecto físico que provoca la dispersión de los granos de cemento acelerando su velocidad de hidratación y la precipitación de carboaluminatos de calcio hidratado (1). El efecto de la dispersión se atribuye a la ubicación de la caliza entre los granos de cemento que aumenta el área de contacto grano de clínker-agua y posibilita un incremento en la velocidad de hidratación inicial. Además, algunos autores (2-3) atribuyen este incremento a que las partículas de la caliza actúan como centros de nucleación alrededor de los cuales se depositan los cristales de $\mathrm{CH}$ (efecto filler). Desde el punto de vista de la resistencia, el efecto filler produce un aumento de este parámetro a edades tempranas. Sin embargo, como con la incorporación de caliza al cemento no se generan productos de hidratación con características cementantes (4) los cementos con este tipo de adición registran a edades avanzadas un escaso aumento en la resistencia (5).

La incorporación de escoria como adición en el cemento Portland ocasiona principalmente la formación de $\mathrm{CSH}$ con características similares al que se produce durante la hidratación de los silicatos de calcio del clínker Portland (6). La reacción es relativamente lenta, razón por la cual la ganancia de resistencia asociada es diferida en el tiempo (7). Con el progreso de la reacción además de la manifestación química habrá una manifestación física que consistirá en un refinamiento de poros en la matriz de cemento (8).

En este trabajo se analiza la influencia del reemplazo de cemento Portland normal por cantidades variables de escoria de alto horno (hasta un 20\%) y/o caliza (hasta un $20 \%$ ) sobre el estado fresco, la resistencia mecánica y el grado de hidratación de los hormigones con ellos elaborados. El estudio se realizó empleando un diseño de mezclas Simplex a partir del cual se determinó la interdependencia de las adiciones y sus efectos sobre la resistencia mecánica del hormigón.

\section{PARTE EXPERIMENTAL}

Cementos: para el programa de ensayos se utilizó un cemento Portland sin adición (CPN) con un $58 \%$ de $\mathrm{C}_{3} \mathrm{~S}, 18 \%$ de $\mathrm{C}_{2} \mathrm{~S}, 2 \%$ de $\mathrm{C}_{3} \mathrm{~A}$ y $13 \%$ de $\mathrm{C}_{4} \mathrm{AF}$ y dos cementos Portland con caliza, obtenidos a partir del mismo clínker Portland. Los cementos pertenecen a la emissions it provides. The three-way benefits generated by the replacement of cement with additions include the solution of certain technological problems, cost savings and lower environmental impact.

The use of limestone as a partial replacement for clinker disperses the cement particles, accelerating their hydration rate along with the precipitation of hydrated calcium carboaluminates (1). This physical effect is attributed to limestone interspersion among the cement particles, which increases the area of the clinker-water interface and with it the initial hydration rate. Some authors (2-3) attribute this increase to the fact that the limestone particles act as nucleation hubs where $\mathrm{CH}$ crystals form. Known as the filler effect, this development raises early age strength. Since the inclusion of limestone in cement does not generate cementitious hydration products (4), however, at later ages cement strength remains essentially unaffected by this addition (5).

Primarily, adding slag to Portland cement induces the formation of $\mathrm{CSH}$ with characteristics similar to the gel generated during the hydration of the calcium silicates in Portland clinker (6). The associated gain in strength appears in the medium term, for this is a relatively slow reaction (7) whose effect is progressively enhanced by a physical development: namely the pore size refinement in the cement matrix (8).

This paper analyzes the effect of replacing ordinary Portland cement with variable amounts of blast furnace slag (up to 20\%) and/or limestone (up to 20\%) on early age properties, mechanical strength and degree of hydration of the concretes made with these materials. The study was designed around a Simplex mixture approach to facilitate the determination of the interdependence between the additions and their effects on concrete strength.

\section{EXPERIMENTAL PART}

Cements: the test programme called for an unadditioned Portland cement (CPN) containing 58\% $C_{3} S$, $18 \% C_{2} S, 2 \% C_{3} A$ and $13 \% C_{4} A F$, as well as two limestone-Portland blended cements manufactured from the same Portland clinker. CP40 $\left(f^{\prime}{ }_{c}>40 \mathrm{MPa}\right.$ after 28 
clase resistente CP40 $\left[\mathrm{f}^{\prime}{ }_{\mathrm{c}}>40 \mathrm{MPa}\right.$ a 28 días ensayados sobre prismas $\left(40 \times 40 \times 160 \mathrm{~mm}^{3}\right)$ de morteros ISO-RILEM] y su finura Blaine fue de $321 \mathrm{~m}^{2} / \mathrm{kg}$ para el cemento CPN, y 380 y $383 \mathrm{~m}^{2} / \mathrm{kg}$ para los cementos con 12 (CP12F) y 18\% (CP18F) de caliza.

Adición mineral: como adición mineral se utilizó escoria granulada de alto horno, con una finura Blaine de 458 $\mathrm{m}^{2} / \mathrm{kg}$, un módulo químico $(C+M+A / S)$ de 1,8 . El contenido de escoria incorporado en ambos cementos fue de hasta $20 \%$ en peso. Éste fue adoptado en función que estudios recientes (9) realizados sobre morteros ISORILEM mostraron que la combinación de $10-15 \%$ de caliza y $20 \%$ de escoria producen excelentes niveles resistentes en el cemento ternario.

Agregados: como árido grueso se utilizó una piedra de machaqueo granítica con tamaño máximo de $19 \mathrm{~mm}$, y como árido fino una arena natural silícea con módulo de finura de 2,35 .

Proporciones de las mezclas: con los materiales antes descriptos se elaboraron hormigones con 350 $\mathrm{kg} / \mathrm{m}^{3}$ de material cementante, relación agua/material cementante $(\mathrm{a} / \mathrm{mc})$ de 0,50 , relación árido fino/árido total de 0,45 y un asentamiento plástico (100 $\pm 20 \mathrm{~mm})$. La Tabla 1 muestra las proporciones de los hormigones estudiados.

Estado fresco: la determinación del asentamiento, la exudación y el tiempo de fraguado se realizó de acuerdo a las normas ASTM C 143, C 403 y C 232, respectivamente.

Propiedades mecánicas: el módulo de rotura fue determinado a partir de la resistencia a flexión en probetas prismáticas $(10 \times 15 \times 52 \mathrm{~cm})$ de acuerdo a la norma ASTM C 293, mientras que la resistencia a compresión se realizó sobre probetas cilíndricas $(10 \times 20 \mathrm{~cm})$ de acuerdo a la norma ASTM C 39. El curado de las probetas fue de 24 horas en el molde y luego de desmoldadas se sumergieron en agua saturada con cal hasta la edad de ensayo $(3,7,28,90$ y 360 días).

I nfluencia del tiempo de curado húmedo: sobre los hormigones elaborados con cementos compuestos binarios y ternarios se analizó la influencia del tiempo de curado húmedo sobre la resistencia a compresión. Los curados estudiados se indican en la Tabla 2 y las edades de ensayo fueron 3, 7 y 28 días.

La condición de humedad de las probetas al momento de los ensayos fue la resultante del intercambio entre éstas y el medio ambiente. En consecuencia, las únicas probetas que se encontraban en estado saturado, al momento del ensayo, fueron las correspondientes al curado húmedo (D). days, tested on ISO-RILEM mortar specimens ( $40 \times 40$ $x 160 \mathrm{~mm}^{3}$ ) cements were used, with Blaine fineness values of $321 \mathrm{~m}^{2} / \mathrm{kg}$ for the CPN and 380 and 383 $\mathrm{m}^{2} / \mathrm{kg}$ for the cements with $12 \%$ (CP12F) and $18 \%$ (CP18F) limestone.

Mineral addition: granulated blast furnace slag was used as the addition, with a Blaine fineness of $458 \mathrm{~m}^{2} / \mathrm{kg}$ and a chemical module $(C+M+A / S)$ of 1.8 . Up to $20 \%$ of slag by weight was added to both cements. This ceiling was adopted on the grounds of the findings of recent studies on ISO-RILEM mortars (9) showing that ternary cement with a combination of $10-15 \%$ limestone and $20 \%$ slag exhibited excellent strength values.

Aggregate: crushed granite with a maximum particle size of $19 \mathrm{~mm}$ was used as the coarse aggregate, while the filler were natural siliceous sand with a fineness modulus of 2.35 .

Mixture proportions: the above materials were used to manufacture concrete with $350 \mathrm{~kg} / \mathrm{m}^{3}$ of cementitious material, a water/cementitious material $(w / \mathrm{cm})$ ratio of 0.50 , a fine/coarse aggregate ratio of 0.45 and a plastic slump (100 $\pm 20 \mathrm{~mm})$. Table 1 gives the composition of the concretes studied.

Early age properties: slump, bleeding and setting time were found as per ASTM standards C 143, C 403 and C 232, respectively.

Mechanical properties: the modulus of rupture was found from the flexural strength determined on prismatic specimens $(10 \times 15 \times 52 \mathrm{~cm})$ as described in ASTM standard C 293, while compressive strength was determined on cylindrical $(10 \times 20-\mathrm{cm})$ specimens in accordance with ASTM standard C 39. Specimens were cured for 24 hours in the mould and submerged after demoulding in lime-saturated water until the test age $(3,7,28$, 90 and 360 days).

Effect of damp curing time: the effect of damp curing time on binary and ternary blended cement concrete compressive strength was likewise found. The curing times studied are shown in Table 2 ; three-, seven- and 28-day specimens were tested.

Specimen dampness at testing was the result of sample exposure to the environment. Consequently, the only specimens that were saturated at testing were those cured under method $(D)$. 
Tabla 1 / Table 1

Proporciones de los hormigones con cementos binarios y ternarios Composition of binary and ternary blended cement concrete

\begin{tabular}{|c|c|c|c|c|c|c|}
\hline \multirow{3}{*}{$\begin{array}{l}\text { Tipo de cemento } \\
\text { Type of cement }\end{array}$} & \multicolumn{6}{|c|}{ Materiales, $\mathbf{k g} / \mathbf{m}^{3} /$ Materials, $\mathrm{kg} / \mathrm{m}^{3}$} \\
\hline & Agua & Cemento & Caliza* & Escoria & Árido fino & Árido grueso \\
\hline & Water & Cement & Limestone* & Slag & Fine aggregate & Coarse aggregate \\
\hline CPN & 175 & 350 & - & - & 840 & 1000 \\
\hline $\mathrm{CP} 12 \mathrm{~F}$ & 175 & 308 & 42 & - & 834 & 1000 \\
\hline CP18F & 175 & 287 & 63 & - & 831 & 1000 \\
\hline $\mathrm{CPN}+20 \mathrm{E}$ & 175 & 280 & - & 70 & 831 & 1000 \\
\hline $\mathrm{CP} 12 \mathrm{~F}+10 \mathrm{E}$ & 175 & 277 & 38 & 35 & 830 & 1000 \\
\hline $\mathrm{CP} 12 \mathrm{~F}+20 \mathrm{E}$ & 175 & 246 & 34 & 70 & 827 & 1000 \\
\hline $\mathrm{CP} 18 \mathrm{~F}+10 \mathrm{E}$ & 175 & 255 & 60 & 35 & 826 & 1000 \\
\hline $\mathrm{CP} 18 \mathrm{~F}+20 \mathrm{E}$ & 175 & 230 & 50 & 70 & 825 & 1000 \\
\hline
\end{tabular}

* Valor calculado del contenido de caliza en el cemento.

* Computed from the limestone content in the cement.

Tabla 2 / Table 2

Tiempos de curados estudiados Curing times

\begin{tabular}{|c|c|c|c|}
\hline $\begin{array}{l}\text { Notación } \\
\text { Notation }\end{array}$ & $\begin{array}{l}\text { Duración total } 28 \text { días } \\
\text { Total duration } 28 \text { days }\end{array}$ & & \\
\hline Curado A & $24 \mathrm{~h}$ en moldes & Al aire (ambiente de laboratorio) & \\
\hline Curing method $A$ & 24 hours in moulds & Air-cured (laboratory temperature) & \\
\hline Curado B & $24 \mathrm{~h}$ en moldes & 2 días en agua & Al aire (ambiente de laboratorio) \\
\hline Curing method $B$ & 24 hours in moulds & 2 days in water & Air-cured (laboratory temperature) \\
\hline Curado C & $24 \mathrm{~h}$ en moldes & 6 días en agua & Al aire (ambiente de laboratorio) \\
\hline Curing method $C$ & 24 hours in moulds & 6 days in water & Air-cured (laboratory temperature) \\
\hline Curado D & $24 \mathrm{~h}$ en moldes & En agua $(20 \pm 2 \stackrel{\circ}{ })$ & \\
\hline Curing method $D$ & 24 hours in moulds & In water $(20 \pm 2 \stackrel{\circ}{ } \mathrm{C})$ & \\
\hline
\end{tabular}

Agua no evaporable: los fragmentos obtenidos del ensayo a compresión se molieron para la determinación de la cantidad de agua no evaporable de acuerdo al procedimiento propuesto por Powers (10). Este valor se utilizó como estimador del progreso de la reacción de hidratación, asumiendo que la caliza es hidráulicamente no activa y que la totalidad de la escoria incorporada reacciona para producir $\mathrm{CSH}$.

Modelo de estudio: para la modelización de los hormigones en base a su comportamiento mecánico se utilizó el diseño de mezclas denominado Simplex (11) considerando como variables, a los tres componentes del sistema: cemento Portland, caliza y escoria. Con las resistencias de cada uno de los siete puntos que conforman el diseño experimental y el punto de ajuste del modelo (CP12F) (Figura 1), se determinó la expresión que relaciona la respuesta mecánica y el conjunto de variables para cada edad estudiada. La ecuación del modelo está dada por la expresión [1]:

$$
Y_{(n)}=a X_{1}+b X_{2}+c X_{3}+d X_{1} X_{2}+e X_{1} X_{3}+f X_{2} X_{3}+g X_{1} X_{2} X_{3}
$$


donde $Y_{(n)}$ es la resistencia mecánica a la edad de $n$ días, $X_{1}$ es el porcentaje de caliza, $X_{2}$ es el porcentaje de escoria, $X_{3}$ es el porcentaje de cemento Portland, y a, b, $c, d$, e, $f$ y $g$ son los coeficientes del sistema obtenidos usando el método de mínimos cuadrados. Los valores de resistencia obtenidos a partir de la expresión anterior no difirieron en más del $6 \%$ con respecto a los resultados experimentales.

\section{RESULTADOS}

Asentamiento: en la Tabla 3 se puede observar que el asentamiento se mantuvo en $100 \pm 20 \mathrm{~mm}$ para todas las mezclas estudiadas, a pesar del incremento en la superficie específica del material cementante de 321 hasta $400 \mathrm{~m}^{2} / \mathrm{kg}$. Resultados similares se obtuvieron en estudios anteriores (9) realizados sobre morteros con reemplazo parcial de cemento por caliza (10 y 20\%) y escoria $(10,20$ y $35 \%$ ) y relación a/mc de 0,50 , pues la incorporación conjunta de estas adiciones no modificó la demanda de agua para obtener un escurrimiento aproximadamente constante (111 a 122\%) en la mesa de asentamiento (flow). El comportamiento observado puede atribuirse por una parte a que es común el empleo de aditivos ayuda molienda en la fabricación del cemento Portland con caliza, el cual puede incorporar aire y aumentar el asentamiento de las mezclas.

Por otra parte, el incremento de la cantidad de agua necesaria para lubricar los granos de cemento puede ser compensado por la disminución del agua químicamente combinada en los productos de hidratación en la etapa inicial y durante el periodo durmiente, y la menor cantidad de agua que se requiere para lubricar estos productos, debido a la disminución de material cementante inicialmente reactivo. where: $Y_{(n)}$ is the mechanical strength at age $n$ (in days), $X_{1}$ is the percentage of limestone, $X_{2}$ the percentage of slag, $X_{3}$ the percentage of Portland cement, and $a, b, c$, $d, e, f$ and $g$ the system coefficients found with the minimum squares method. The strength values obtained from the above expression differed from the experimental results by less than $6 \%$.

\section{RESULTS}

Slump: as Table 3 shows, slump remained unchanged at $100 \pm 20 \mathrm{~mm}$ for all the blends studied, despite the increase -from 321 to $400 \mathrm{~m}^{2} / \mathrm{kg}$ - in BET specific surface of the cementitious material. Similar results had been found in previous studies (9) on mortars with a $w / \mathrm{cm}$ ratio of 0.50 , in which cement was partially replaced by limestone (10 and 20\%) and slag (10, 20 and $35 \%)$, for the joint inclusion of these two additions was observed to have no effect on the amount of water needed to obtain an approximately constant flow (111 to $122 \%)$. Such behaviour may be attributed on the one hand to the fairly common use of grinding aids in the manufacture of limestone blend Portland cements, a procedure that may involve air entrainment, thereby increasing slump.

On the other hand, the expected increase in the amount of water needed to hydrate the cement particles may be offset by two effects: the decline in chemically combined water in the hydration products during the initial stage and throughout the dormant period, and the lesser amount of water needed to hydrate these products due to the smaller amount of initially reactive cementitious material.

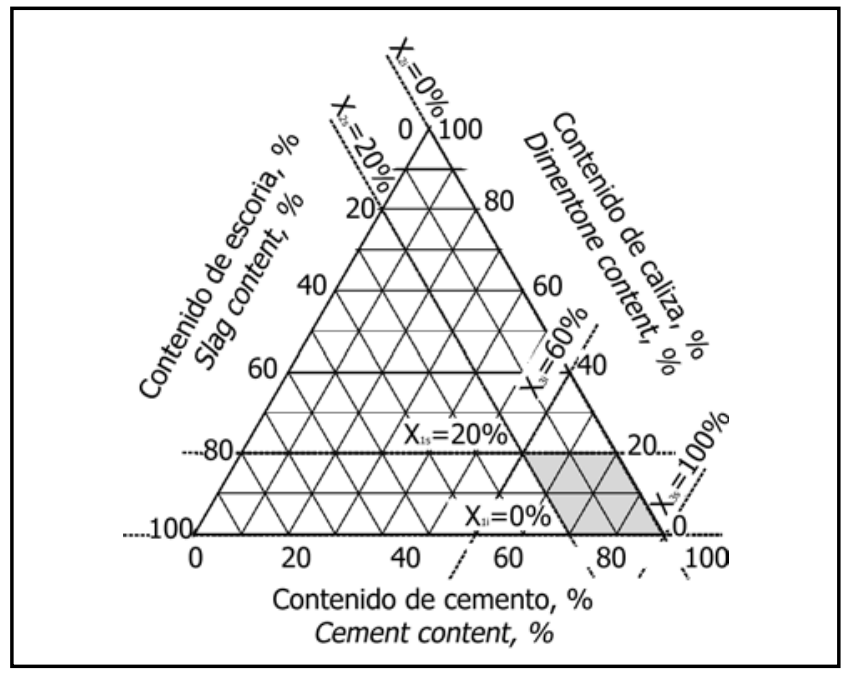

Figura 1. Dominio del diseño experimental.

Figure 1. Experimental design domain. 
Tabla 3 / Table 3

Características en estado fresco de los hormigones estudiados

Composition of binary and ternary blended cement concrete

\begin{tabular}{|c|c|c|c|c|c|}
\hline \multirow[b]{2}{*}{$\begin{array}{l}\text { Hormigón } \\
\text { Concrete }\end{array}$} & \multirow[b]{2}{*}{$\begin{array}{l}\text { Asentamiento, } \mathbf{m m} \\
\text { Slump, } \mathrm{mm}\end{array}$} & \multicolumn{2}{|c|}{ Fraguado, horas / Setting, hours } & \multicolumn{2}{|c|}{ Exudación / Bleeding } \\
\hline & & $\begin{array}{l}\text { Inicial } \\
\text { Initial }\end{array}$ & $\begin{array}{l}\text { Final } \\
\text { End }\end{array}$ & $\begin{array}{c}\text { Capacidad, \% } \\
\text { Capacity, \% }\end{array}$ & $\begin{array}{c}\text { Velocidad, } \mathrm{cm}^{3} / \mathrm{cm}^{2} \mathrm{~s} \\
\text { Rate, } \mathrm{cm}^{3} / \mathrm{cm}^{2} \mathrm{~s}\end{array}$ \\
\hline CPN & 85 & 6,39 & 9,57 & 15,4 & $4,0 \times 10-5$ \\
\hline $\mathrm{CP} 12 \mathrm{~F}$ & 115 & 6,55 & 9,20 & 11,4 & $2,5 \times 10-5$ \\
\hline $\mathrm{CP} 18 \mathrm{~F}$ & 80 & 6,70 & 9,40 & 4,9 & $7,1 \times 10-6$ \\
\hline $\mathrm{CPN}+20 \mathrm{E}$ & 100 & 6,28 & 9,99 & 14,8 & $3,1 \times 10-5$ \\
\hline $\mathrm{CP} 12 \mathrm{~F}+10 \mathrm{E}$ & 120 & 6,59 & 9,63 & 9,7 & $2,1 \times 10-5$ \\
\hline $\mathrm{CP} 12 \mathrm{~F}+20 \mathrm{E}$ & 105 & 6,43 & 9,32 & 9,5 & $2,1 \times 10-5$ \\
\hline $\mathrm{CP} 18 \mathrm{~F}+10 \mathrm{E}$ & 110 & $6: 25$ & $9: 28$ & 6,2 & $1,4 \times 10-5$ \\
\hline $\mathrm{CP} 18 \mathrm{~F}+20 \mathrm{E}$ & 105 & 6,31 & 8,27 & 7,5 & $1,9 \times 10-5$ \\
\hline
\end{tabular}

Tiempo de fraguado: el tiempo de fraguado inicial y final registrado por los hormigones (Tabla 3 ) también se mantuvo prácticamente constante $(6,5 \pm 0,2$ y 9,6 $\pm 0,4 \mathrm{~h})$. En consecuencia, la menor cantidad de material reactivo disponible en los hormigones con adición es compensada por la aceleración inicial de las reacciones de hidratación del clínker Portland producida por la incorporación de materiales finamente molidos.

Exudación: cuando se mantiene constante la relación $a / m c$, el contenido de cemento y el contenido y tipo de agregados, la capacidad de exudación depende, en gran medida, del tipo de cemento empleado. La exudación de los hormigones estudiados resultó no canalizada con velocidades decrecientes a medida que aumenta el contenido de caliza en el cemento compuesto (Tabla 3). A pesar de las diferencias importantes que existen entre las finuras de los cementos, la capacidad de exudación fue definida fundamentalmente por la presencia de la caliza, pues los hormigones $\mathrm{CP} 12 \mathrm{~F}+10 \mathrm{E}$ y $\mathrm{CP} 12 \mathrm{~F}+20 \mathrm{E}$ tienen una capacidad de exudación similar entre sí y $38 \%$ menor al hormigón CPN. En tanto que el hormigón CP18F+20E presenta una reducción de la capacidad de exudación del $51 \%$ con respecto al hormigón CPN. Resultados similares se han observado en hormigones elaborados con cemento con y sin adición de caliza e igual clase resistente (12). Este comportamiento puede atribuirse a que la caliza obstruye los capilares dificultando el flujo de agua desde la masa de hormigón (13).

Resistencia: la Figura 2a muestra el análisis tradicional del desarrollo de la resistencia a compresión de los hormigones conteniendo los cementos CPN, CP18F, $\mathrm{CPN}+20 \mathrm{E}$ y $\mathrm{CP} 12 \mathrm{~F}+20 \mathrm{E}$. En la misma se puede observar que a edades tempranas ( 3 y 7 días) el hormigón con CP18F registra una resistencia a compresión superior a la obtenida por el hormigón con CPN, a 28 días ambos hormigones presentan una resistencia similar, en tanto que entre 90 y 360 días el hormigón con CP18F registra
Setting time: the beginning and end setting times recorded for the concretes (Table 3) also remained essentially unchanged $(6.5 \pm 0.2$ y $9.6 \pm 0.4 \mathrm{~h})$, a sign that the lesser amount of reactive material available in the concretes with additions was offset by the acceleration of the initial Portland clinker hydration reactions, in turn induced by the inclusion of finely ground materials.

Bleeding: when the $w / \mathrm{cm}$ ratio, cement content and aggregate content and type are kept constant, bleeding depends largely on the type of cement used. In the concretes studied, bleeding rates did not decline with increasing limestone content in the blended cement (Table 3). Despite the substantial differences in cement fineness, bleeding depended essentially on the presence of limestone, for bleeding rates were similar in concretes $C P 12 F+10 E$ and $C P 12 F+20 E$ and $38 \%$ lower in both than in $C P N$ concrete. Concrete $C P 18 F+20 E$, in turn, exhibited $51 \%$ less bleeding than the CPN concrete. A previous survey (12) yielded similar results for concretes made from a series of cements in the same strength class, with or without limestone additions. Such behaviour can be attributed to the fact that the limestone clogs capillaries, obstructing the flow of water from the concrete mix (13).

Strength: Figure 2a shows a traditional analysis of compressive strength development in concretes with CPN, $C P 18 F, C P N+20 E$ and $C P 12 F+20 E$ cement. Note that at early ages ( 3 and 7 days) compression strength was higher in concrete with CP18F than CPN concrete, after 28 days the two concretes exhibited similar strength values and after 90 and 360 days the CP18F concrete was slightly stronger. Compressive strength was lower in $C P N+20 E$ than in CPN concrete up to the age of 28 days, but $6 \%$ 
una resistencia levemente menor. En el hormigón con $C P N+20 E$, la resistencia a compresión es más baja que la correspondiente al hormigón con CPN hasta los 28 días, alcanzando a 360 días un aumento de resistencia del orden del $6 \%$ con respecto a éste. Por otra parte, a partir de los 7 días el desarrollo de la resistencia del hormigón con $\mathrm{CP} 12 \mathrm{~F}+20 \mathrm{E}$ es comparable al hormigón con CPN.

La Figura $2 b$ muestra el desarrollo del módulo de rotura de los hormigones elaborados con cementos CPN, $\mathrm{CP} 18 \mathrm{~F}, \mathrm{CPN}+20 \mathrm{E}$ y $\mathrm{CP} 12 \mathrm{~F}+20 \mathrm{E}$. En la misma se puede observar que para todas las edades analizadas el módulo de rotura del hormigón con $\mathrm{CP} 18 \mathrm{~F}$ resulta menor que el correspondiente al hormigón con CPN, alcanzando a ser esta disminución del 4\% a los 360 días. Contrariamente, a partir de los 3 días, el módulo de rotura del hormigón elaborado con CPN $+20 \mathrm{E}$ es superior al obtenido por el hormigón con CPN (10\% mayor a 360 días), mientras que el desarrollo del módulo de rotura del hormigón con $\mathrm{CP} 12 \mathrm{~F}+20 \mathrm{E}$ presenta un comportamiento similar al registrado por el hormigón con CPN hasta los 28 días, en tanto que a 360 días este parámetro es 14\% mayor que el correspondiente al hormigón CPN.

Curvas de isorrespuestas: con el propósito de analizar la interdependencia factorial entre la escoria y la caliza en el cemento Portland y su influencia sobre la resistencia a una edad preestablecida, se analizan las curvas de isorrespuesta correspondientes al dominio dado por: caliza $\left(X_{1}\right)+$ escoria $\left(X_{2}\right) \leq 40 \%$, con $X_{1} \leq 20 \%$ y $X_{2} \leq 20 \%$ (Figuras 3 y 4 ).

La Figura 3a muestra que a tres días, la región de máxima resistencia a compresión (> $20 \mathrm{MPa}$ ) se obtiene para contenidos de hasta $20 \%$ de $X_{1} y / 012 \%$ de $X_{2}$, resultando esta región con una resistencia $20 \%$ mayor que la correspondiente al hormigón con CPN. Las curvas de isorrespuestas a 7 días (Figura 3b) muestran un corrimiento de la zona de máxima resistencia (> $29 \mathrm{MPa}$ ), ubicándose higher after 360 days. Moreover, after seven days, strength development in $C P 12 F+20 E$ concrete was comparable to development in CPN concrete.

Figure $2 b$ shows the modulus of rupture for concretes made with CPN, CP18F, CPN+20E, and CP12F+20E cement. The modulus of rupture for CP18F concrete was smaller than for CPN concrete in all the ages analyzed, with the decline coming to $4 \%$ after 360 days. Conversely, after three days the modulus of rupture for CPN+20E concrete was higher than the value for CPN concrete $110 \%$ higher after 360 days). The pattern followed in the first 28 days by the modulus of rupture for $C P 12 F+20 E$ concrete, in turn, was similar to the behaviour observed in CPN concrete, whereas after 360 days this parameter was 14\% higher in $C P 12 F+20 E$ than CPN concrete.

Iso-response contours: the iso-response lines for the domain defined as: limestone $\left(X_{1}\right)+\operatorname{slag}\left(X_{2}\right) \leq 40 \%$, with $X_{1} \leq 20 \%$ and $X_{2} \leq 20 \%$ (Figures 3 and 4) were analyzed to ascertain the factorial interdependence between slag and limestone in Portland cement and the effect of these additions on strength at a pre-established age.

Figure $3 a$ shows that after three days, the maximum compressive strength area (> $20 \mathrm{MPa}$ ) concurred with $X_{1}$ contents of up to $20 \%$ and/or $X_{2}$ of $12 \%$; strength in this region was $20 \%$ greater than in CPN concrete. After seven days, the contours (Figure $3 b$ ) indicate a shift in the maximum strength area (> $29 \mathrm{MPa}$ ) to around $10 \%$ limestone and $10 \%$ slag. After 28 days, all concrete
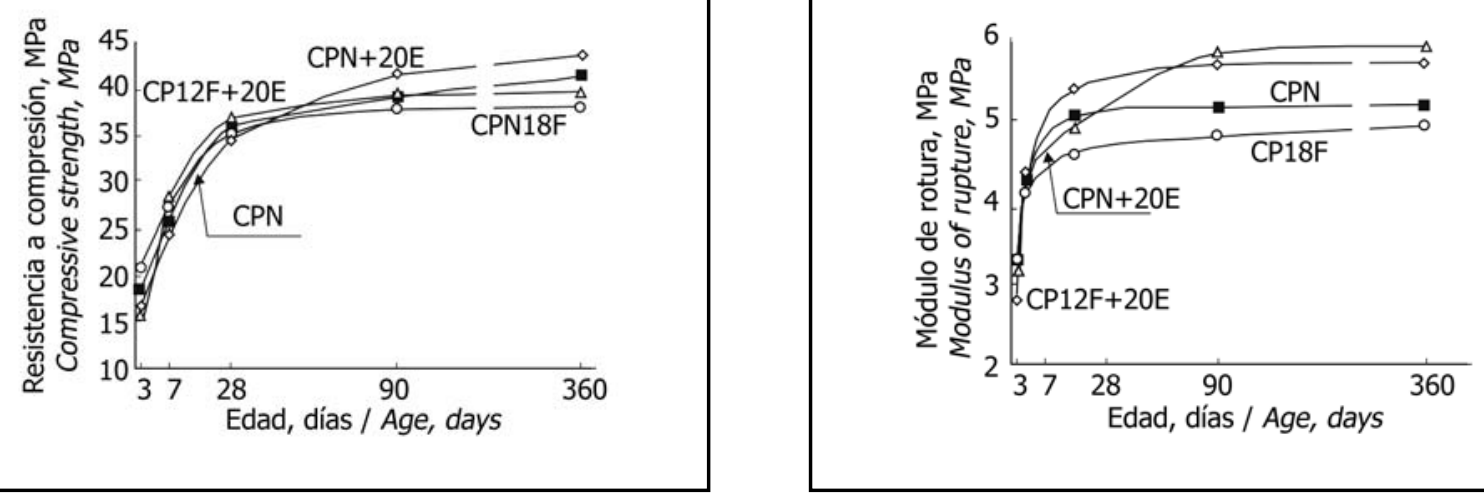

Figura 2. Evolución de la resistencia de los hormigones. a) Compresión y b) Flexión. Figure 2. Strength patterns. a) Compressive and b) Flexural. 
alrededor de $10 \%$ de caliza y $10 \%$ de escoria. A 28 días, la totalidad de las resistencias se encuentran entre $36 \pm 1$ $\mathrm{MPa}$, sin embargo, el contorno de las curvas cambia de manera singular (Figura $3 c$ ), pues se tornan más o menos paralelas al contenido de $X_{1}$ y la resistencia depende en mayor medida de este valor. A 90 y 360 días (Figura 3d y e) las curvas de isorrespuestas presentan contornos similares, registrando los máximos valores de resistencias en la zona del dominio con contenidos más elevados de $X_{2}$. A estas edades, los hormigones con hasta $5 \%$ de $X_{1}$ y $20 \%$ de $X_{2}$ registran resistencias $7 \%$ mayores que el hormigón con CPN.

En la Figura 4 se muestran las curvas de isorrespuestas de la resistencia a flexión. A 3 días (Figura 4a) la máxima combinación de niveles de $X_{1}$ y $X_{2}$ que permite alcanzar la zona correspondiente al máximo módulo de rotura $(3,6 \mathrm{MPa})$ se obtiene con el hormigón $(10,10)$, resultando éste ser un $10 \%$ mayor que el registrado por el hormigón con CPN. A 28 días, las curvas de isorrespuesta muestran un corrimiento de la zona de máximo módulo de rotura hacia los niveles más bajos de $X_{1}$ (Figura $4 b$ ) indicando que la resistencia es mayormente dependiente del nivel que adopte el valor $X_{1}$. Por último a 360 días (Figura 4c), la zona correspondiente al máximo módulo de rotura se obtiene con cualquier nivel de $X_{1}$ y con valores strength values were found to be at around $36 \pm 1 \mathrm{MPa}$ and the striking change in contour shape, which approximately parallels the $X_{1}$ content (Figure $3 c$ ), infers that strength depends more on this than on the other two values. After 90 and 360 days (Figures $3 d$ and e) the isoresponse contours are similarly shaped, with maximum strength values being found in the domain where $X_{2}$ content is highest. At these ages concretes with up to $5 \%$ of $X_{1}$ and $20 \%$ of $X_{2}$ exhibit strength values $7 \%$ higher than CPN concrete.

The flexural strength iso-response contours are given in Figure 4. After three days (Figure 4a) the ceiling values for $X_{1}$ and $X_{2}$ yielding the maximum modulus of rupture (3.6 $\mathrm{MPa}$ ) were obtained with concrete $(10,10)$, which exhibited 10\% higher strength than CPN concrete. The 28-day isoresponse contours reflect a shift in the maximum modulus of rupture area to lower levels of $X_{1}$ (Figure $4 b$ ), from which it may be deduced that strength depends primarily on the value of that parameter. Lastly, after 360 days (Figure $4 \mathrm{c}$ ) the area corresponding to the maximum modulus of rupture -whose value was up to $14 \%$ higher than in CPN concrete- was obtained for any value of $X_{1}$ and values of $X_{2}>15$. Here the iso-response lines show that

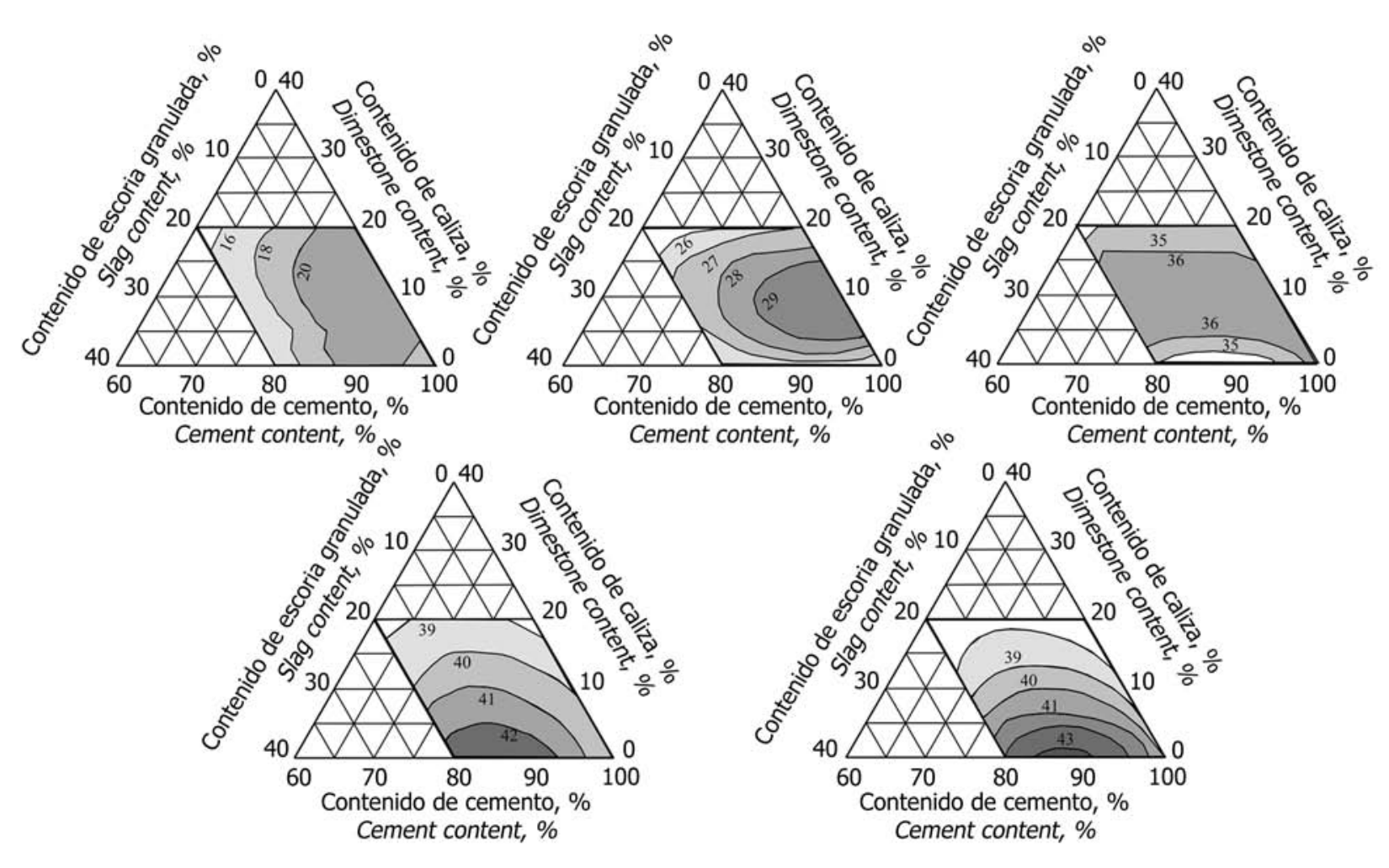

Figura 3. Curvas de isorrespuestas de la resistencia a compresión. a) 3 días, b) 7 días, c) 28 días, d) 90 días y e) 360 días. Figure 3. Compressive strength iso-response contours. a) 3 days, b) 7 days, c) 28 days, d) 90 days and e) 360 days. 
de $X_{2}>15$, resultando su valor de hasta $14 \%$ mayor que el correspondiente al hormigón con CPN. En esta zona las curvas de isorrespuesta muestran que el módulo de rotura es notablemente dependiente del nivel de $X_{2}$.

Agua no evaporable: en la Figura 5 se muestra el contenido del agua no evaporable relativa al hormigón con $\mathrm{CPN}$, de los hormigones con cementos binarios y ternarios. Para los hormigones con CP12F y CP18F (Figura 5a), la cantidad de agua no evaporable aumenta con el incremento en el contenido de caliza. A la edad de 28 días, el agua no evaporable de estos hormigones es 1,16 y 1,24 veces mayor que la registrada por el hormigón con CPN (efecto filler). A edades avanzadas, el progreso de la hidratación del cemento Portland tiende a minimizar esta ventaja y el efecto de dilución se hace preponderante (1,03 - 1,07 a 360 días).

En el hormigón con CPN+20E, la escoria también produce un efecto filler (14), aun así el efecto de la dilución de los granos de cemento en las primeras edades es preponderante porque la escoria aún no ha reaccionado. the modulus of rupture is largely dependent upon the value of $X_{2}$.

Non-evaporable water: Figure 5 graphs the non-evaporable water content for $C P N$, binary and ternary cement concretes. For $\mathrm{CP} 12 \mathrm{~F}$ and $\mathrm{CP} 18 \mathrm{~F}$ concretes (Figure 5a), the amount of non-evaporable water increased with the limestone content. After 28 days, the non-evaporable water in these concretes was 1.16 and 1.24 times greater than in CPN concrete (filler effect). At later ages, Portland cement hydration progress tended to minimize this advantage, with the dilution effect prevailing (1.03 to 1.07 after 360 days).

Although the slag also prompted a filler effect (14) in the $C P N+20 E$ concrete, cement particle dilution prevailed at early ages before the slag had begun to react.

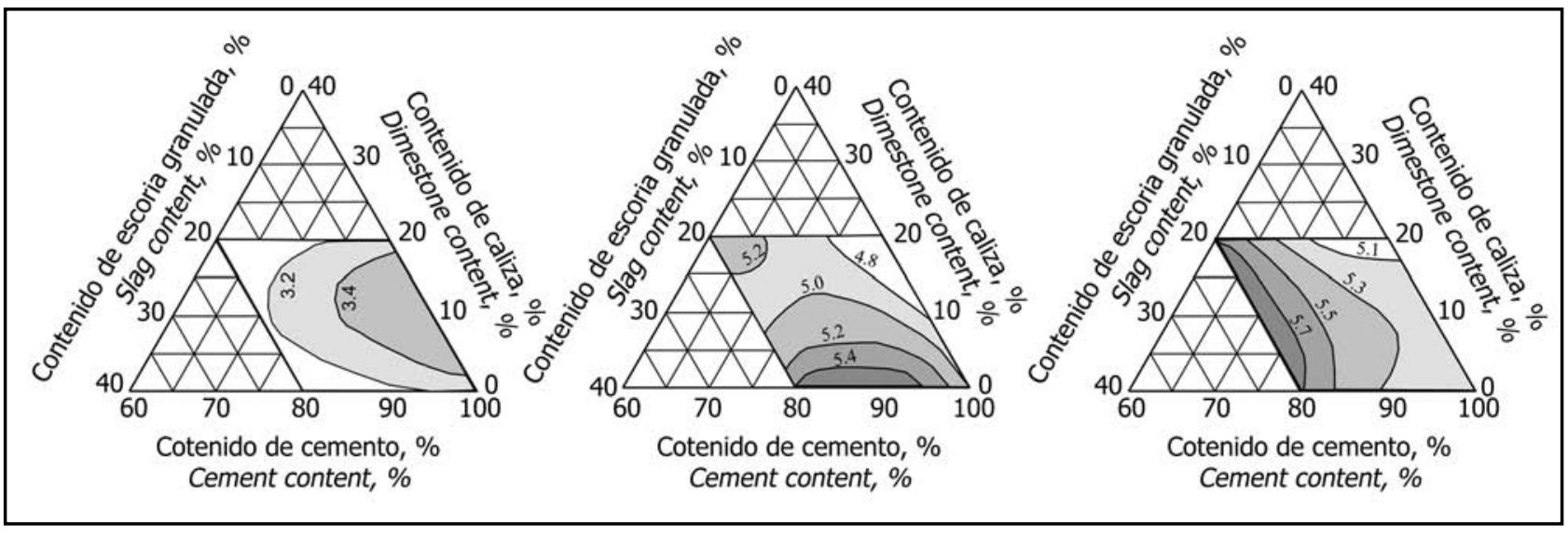

Figura 4. Curvas de isorrespuestas de la resistencia a flexión. a) 3 días, b) 28 días y c) 360 días.

Figure 4. Flexural strength iso-response contours. a) 3 days, b) 28 days and c) 360 days.
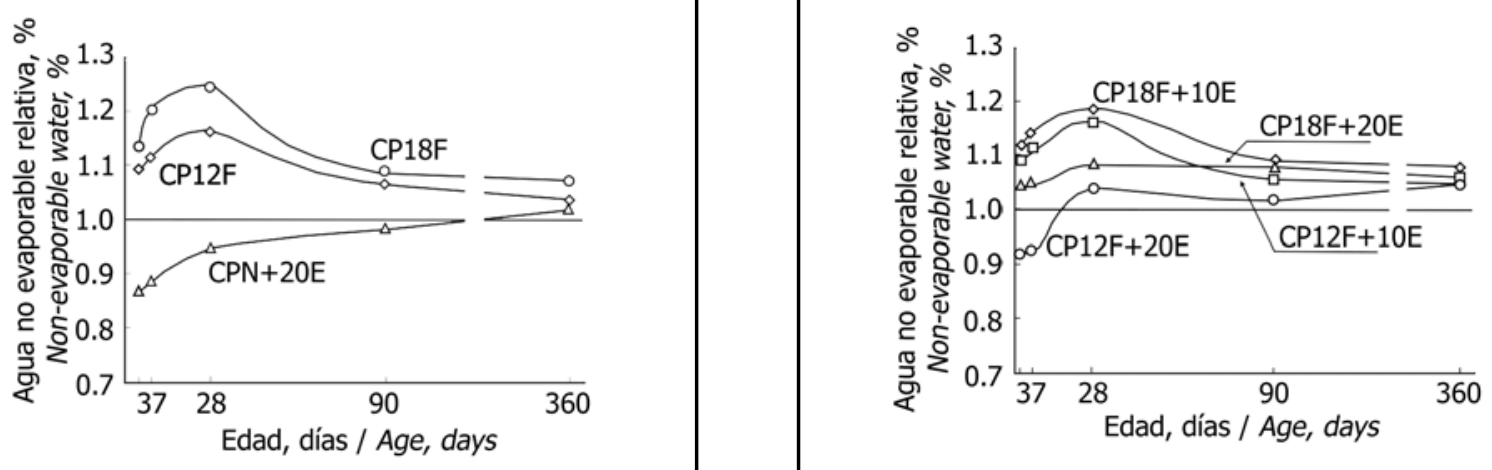

Figura 5. Agua no evaporable de los hormigones elaborados con cementos compuestos. a) Binarios y b) Ternarios. Figure 5. Non-evaporable water in concrete made with blended cements. a) Binary and b) Ternary. 
Después de 7 días, la escoria reacciona formando CSH, y aumenta la cantidad de agua no evaporable, alcanzando este hormigón a la edad de 360 días un valor $2 \%$ mayor que el obtenido por el hormigón con CPN.

La evolución del agua no evaporable para los hormigones elaborados con cementos ternarios se muestra en la Figura 5b. El efecto filler aparece fundamentalmente durante los primeros días de la hidratación y la contribución de la escoria es apreciable luego de los siete días. A 360 días, el agua no evaporable de todos los hormigones con cemento ternario es levemente mayor $(1,05)$ que la correspondiente al hormigón con CPN.

Influencia del tiempo de curado húmedo: en la Figura 6 se muestra la evolución de la resistencia para los distintos tiempos de curado húmedo de los hormigones estudiados. Las pérdidas de resistencia a 28 días ocasionadas por los curados A y B con respecto al curado $D$ de cada serie de hormigón son de: 29 y $6 \%, 30$ y $5 \%, 34$ y $11 \%, 36$ y $15 \%$, para los hormigones elaborados con CPN, CP12F+10E, CP12F+20E y CP18F+20E, respectivamente. En el caso del curado $C$, para las cuatro series de hormigones se registra un aumento de resistencia con respecto al curado $D$.

Este comportamiento puede atribuirse a dos efectos antagónicos: la disminución en la ganancia de resistencia a partir de los 7 días por el curado $\mathrm{C}$ y el menor grado de saturación de la probeta al momento del ensayo (15). La superioridad de este último efecto puede justificar el comportamiento registrado por la resistencia a compresión en este curado. En función de los resultados obtenidos, a medida que el contenido de adiciones se incrementa en el cemento ternario, la disminución del tiempo de curado húmedo produce mayores pérdidas de resistencia.
The slag reacted after seven days, forming $\mathrm{CSH}$ with an increase in non-evaporable water; after 360 days this concrete had a $2 \%$ higher content than CPN concrete.

Figure $5 b$ shows non-evaporable water content in concrete made with ternary cements. The filler effect appeared essentially in the first few days of hydration, while the contribution made by slag to this process was visible after seven days. After 360 days, the non-evaporable water content in all ternary cement concretes was slightly higher (1.05) than in CPN concrete.

Effect of damp curing time: Figure 6 plots strength against curing time for the different concretes studied. The 28-day decline in strength values under curing methods $A$ and $B$ compared to method $D$ were, for each series: $29 \%$ and $6 \%, 30 \%$ and $5 \%, 34 \%$ and $11 \%$ and $36 \%$ and $15 \%$, for concretes made with CPN, $C P 12 F+10 E, C P 12 F+20 E$ and $C P 18 F+20 E$, respectively. All four series of concretes exhibited higher strength under curing method $C$ than method $D$.

This finding may be attributed to two opposing effects: the declining strength gain after seven days in curing method $C$ and the lower degree of specimen saturation at testing (15). The prevalence of the latter effect may explain the compressive strength behaviour observed in this type of curing. According to these results, the greater the addition content in ternary cement, the greater is the strength loss owing to reduced damp curing time.

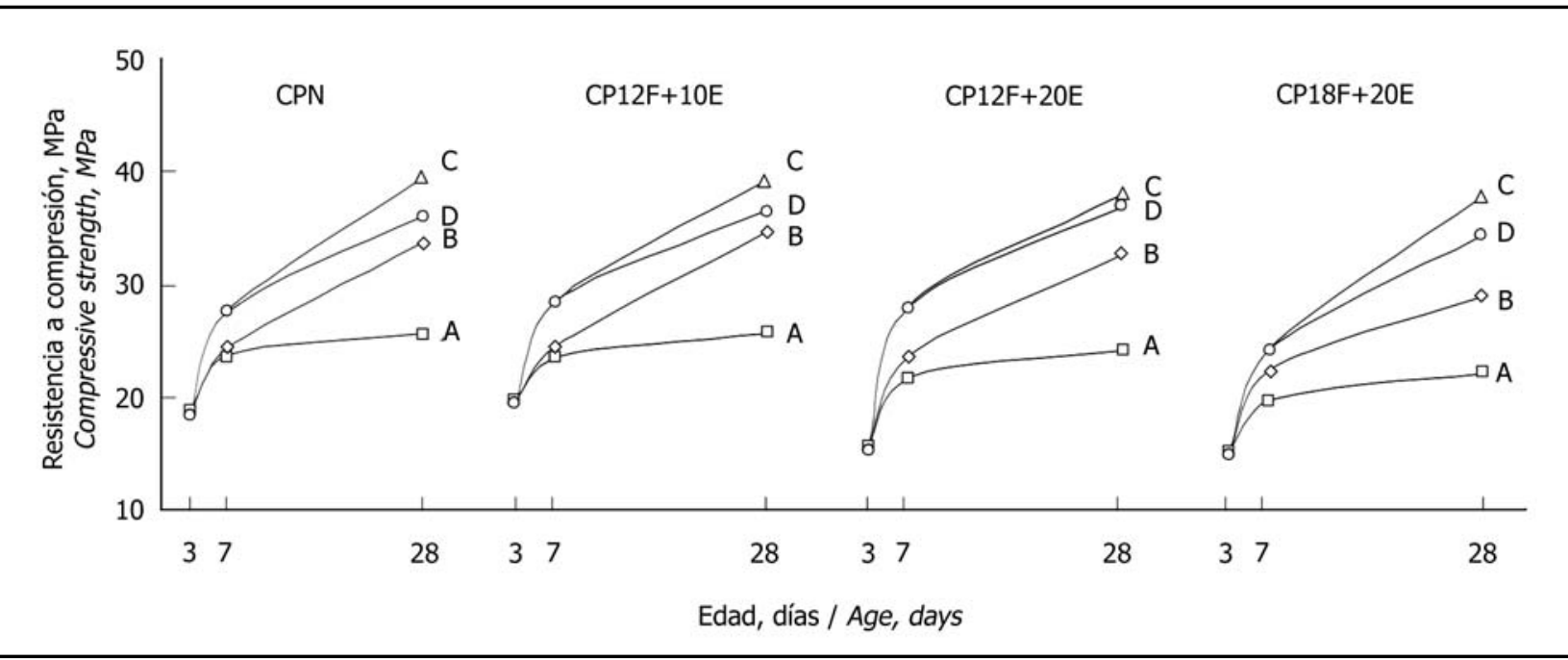

Figura 6. Resistencia a compresión de los hormigones con distintos tiempos de curado húmedo. Figure 6. Concrete compressive strength at different damp curing times. 


\section{DISCUSIÓN}

En función de los resultados obtenidos en los hormigones con curado húmedo continuo; se puede observar que a edades tempranas se puede incorporar hasta $15 \%$ de caliza y $10 \%$ de escoria para obtener la región de máxima resistencia (a compresión o a flexión), este comportamiento puede atribuirse a la aceleración de la hidratación del cemento Portland que producen las adiciones ( 7 , 14). A 28 días la ganancia de resistencia dada por el efecto físico y la reacción de la escoria, compensa el efecto de dilución de los granos de cemento ocasionado fundamentalmente por la caliza (9), en consecuencia, todos los hormigones presentan resistencias similares. Con el transcurso de la hidratación del cemento, el efecto físico provocado por las adiciones disminuye y el efecto de dilución se hace más importante (16). El aumento posterior de la resistencia depende de que la adición pueda generar $\mathrm{CSH}$, por este motivo, luego de 28 días, la zona correspondiente a las máximas resistencias se traslada hacia los niveles más altos de escoria y más bajos de caliza.

Para un determinado clínker Portland, la edad a la cual la escoria contribuye con la hidratación depende del tamaño de sus partículas y su reactividad. La escoria utilizada en este trabajo posee $7 \%$ de partículas más grandes que $45 \mu \mathrm{m}$ y $60 \%$ de partículas más grandes que $10 \mu \mathrm{m}$, con lo cual su contribución a la resistencia se produce luego de los 7 días (17). Finalmente, la combinación del efecto físico sumado a la generación de CSH que produce el refinamiento de grano y poros serán los responsables de contrarrestar al efecto de dilución del cemento Portland (18) y otorgar la continuidad en el desarrollo de la resistencia del cemento ternario.

Adicionalmente, la resistencia del hormigón también depende de la calidad de la zona de transición entre la pasta y el agregado. Esta zona generalmente presenta mayor porosidad debido al efecto pared producido por el agregado, y mayor cantidad y tamaño de los cristales de $\mathrm{CH}$, debido al espacio disponible para su crecimiento (17). El aumento de la resistencia a flexión puede ser atribuido a que, independientemente del tipo de adición mineral que se emplee, el efecto de nucleación produce el reemplazo de cristales grandes y orientados de $\mathrm{CH}$ que conforman los planos de clivajes preferenciales, por cristales pequeños y poco orientados. Esta menor orientación preferencial del $\mathrm{CH}$ mejora sensiblemente la resistencia de la interfase matriz-agregado (19). Detwiler et al. (20) sugieren que, con la incorporación de escoria, este efecto es más importante que el efecto debido al refinamiento de grano, pues la escoria no consume demasiada cantidad de $\mathrm{CH}$ durante su reacción.

Por otra parte, se ha demostrado anteriormente que el cemento con caliza es menos sensible a la interrupción temprana del curado húmedo que el cemento CPN (21),

\section{DISCUSSION}

Pursuant to the results obtained for concrete subjected to continuous damp curing, maximum (flexural or compressive) early age strength is reached with up to $15 \%$ limestone and 10\% slag. This behaviour may be attributed to the acceleration of Portland cement hydration prompted by the additions $(7,14)$. After 28 days the strength gain ensuing from the physical effect and the slag reaction offsets the effect of cement particle dilution resulting primarily from the presence of limestone (9): as a result, strength values are similar in all the concretes. As cement hydration progresses, the physical effect triggered by the additions declines and the dilution effect begins to predominate (16). The subsequent increase in strength depends on whether the addition can generate $\mathrm{CSH}$; for this reason, after 28 days the maximum strength area shifts to higher levels of slag and lower levels of limestone.

For a given Portland clinker, the age at which slag contributes to hydration depends on particle size and reactivity. Since $7 \%$ of the particles in the slag used in this study were over $45 \mu \mathrm{m}$ and $60 \%$ over $10 \mu \mathrm{m}$, its contribution to strength appeared after the seventh day (17). Finally, the physical effect combined with the generation of $\mathrm{CSH}$ that led to particle and pore size refinement countered the effect of Portland (18) cement dilution, thereby assuring strength development in ternary cement.

Moreover, concrete strength also depends on the quality of the interface between paste and aggregate. Porosity is generally greater in this zone due to the wall effect generated by the aggregate: with more space to grow, more and larger $\mathrm{CH}$ crystals appear (17). Increased flexural strength may be attributed to the fact that, regardless of the type of mineral addition used, the nucleation effect occasions a replacement of large, oriented $\mathrm{CH}$ crystals comprising the primary cleavage planes with smaller, more randomly oriented crystals that lead to a substantial improvement in strength at the matrix-aggregate interface (19). Detwiler et al. (20) suggested that with the inclusion of slag, this effect prevails over the effect due to particle size refinement, for slag uptake of $\mathrm{CH}$ during the reaction is relatively small.

Moreover, previous studies (21) have shown that limestone-containing cement is less sensitive than CPN concrete to the early suspension of damp curing because this addition 
debido a que la contribución de esta adición sobre la resistencia está dada en mayor parte por la aceleración de la hidratación del clínker (principalmente del $C_{3} S$ ) (22) a edades tempranas. Contrariamente, debido a que la contribución de la escoria sobre la resistencia está dada fundamentalmente por la formación de CSH y a que la misma se produce con relativa lentitud, la interrupción del curado húmedo afecta en mayor medida a los cementos con escoria que al CPN (23).

Desde este punto de vista, los hormigones elaborados con cemento con contenido variable de caliza y $20 \%$ de escoria resultaron más sensibles a los curados $A$ y $B$ que el hormigón CPN y CP12F+10E, en tanto que todos ellos presentaron un comportamiento similar frente al curado C. En este último caso, el efecto de aceleración del clínker provocado por la caliza compensa en parte la pérdida de resistencia que se produce por la mayor cantidad de escoria que permanece sin reaccionar. Por último, un curado húmedo de 7 días parece ser suficiente para lograr propiedades mecánicas adecuadas tanto en el hormigón con cemento Portland sin adición como en los hormigones con cemento compuesto ternario.

\section{CONCLUSIONES}

Para el sistema ternario cemento Portland-escoria-caliza conteniendo hasta $20 \%$ de caliza y hasta $20 \%$ de escoria se puede concluir que:

- La mezcla ternaria tiene ventajas en cuanto a la resistencia sobre los cementos compuestos binarios y el cemento sin adición. La combinación de caliza y escoria de alto horno es complementaria: la caliza provee la resistencia a temprana edad, mientras que la escoria contribuye con la resistencia a edad avanzada.

- A partir de las curvas de isorrespuesta se pueden definir un gran número de combinaciones de caliza y escoria para alcanzar un determinado nivel de resistencia, pues el modelado de las mismas permite predecir la respuesta de otros puntos sin la realización de esas experiencias.

- Los cementos compuestos ternarios son más afectados por la interrupción temprana del curado húmedo ( 1 y 3 días) que el cemento sin adición y en forma similar, por el curado húmedo de 7 días, resultando este tiempo el mínimo necesario para alcanzar propiedades mecánicas adecuadas.

- El uso de cementos compuestos ternarios conteniendo una adecuada combinación de caliza y escoria de alto horno puede contribuir al desarrollo sostenible de este material, pues disminuye el consumo de recursos no renovables (materiales y combustibles), el gasto de energía en la fabricación del cemento y produce una menor emisión de $\mathrm{CO}_{2}$ al medio ambiente sin comprometer las propiedades mecánicas del hormigón. contributes to strength essentially by accelerating early age clinker (essentially $C_{3} S$ ) hydration (22). Conversely, since the contribution made by slag to strength is largely a result of CSH formation, which takes place at a relatively slow pace, suspension of damp curing affects slag cements more than CPN (23).

This would explain why concretes made with variable limestone content and $20 \%$ slag were more sensitive than CPN and $C P 12 F+10 E$ to curing methods $A$ and $B$, whereas similar behaviour was observed in all under curing method C. In this final case, the clinker acceleration effect prompted by the limestone partially offset the loss of strength caused by the larger unreacted slag content. Lastly, seven-day damp curing appears to suffice to reach suitable mechanical properties both in unadditioned Portland and ternary blended cement concretes.

\section{CONCLUSIONS}

The following conclusions may be drawn with respect to blended slag-limestone Portland cement containing up to $20 \%$ limestone and $20 \%$ slag:

- The ternary mixture affords advantages over binary blended and unadditioned cements. Blast furnace slag and limestone generate complementary effects: limestone provides early age strength, while slag contributes to later age strength.

- Iso-response contours can be used to define a large number of limestone-slag combinations yielding a given strength, since such modelling predicts behaviour at points not actually experimented.

- ternary blended cements are more sensitive to early suspension of (one- and three-day) damp curing than unadditioned cement and particularly to suspension of seven-day damp curing; the latter is the minimum time required to reach the suitable strength.

- The use of ternary blended cements containing an appropriate combination of limestone and blast furnace slag can contribute to the sustainable production of this material, for it signifies lower consumption of nonrenewable resources (materials and fuel) and energy to manufacture cement, as well as the emission of less $\mathrm{CO}_{2}$ into the atmosphere without compromising the mechanical properties of concrete. 


\section{BIBLIOGRAFÍA / BIBLIOGRAPHY}

(1) Bonavetti, V. L.; Rahhal, V. F. y Irassar, E. F.: "Studies on the carboaluminate formation in limestone filler blend", Cement and Concrete Research, vol. 31, № 6 (2001), pp. 883-859.

(2) Soroka, I. y Stern, N.: "Calcareous fillers and the compressive strength of Portland cement". Cement and Concrete Research, vol. 6, no 3 (1976), pp. 367-376.

(3) Bonavetti, V. L. y Irassar, E.: “The effect of stone dust content in sand", Cement and Concrete Research, vol. 24, no 3 (1994), pp. 580-590.

(4) Sersale, K.: "Advances in Portland and Blended Cement", Proc. 9th International Congress of the Chemistry of Cement. New Delhi (India), vol. I (1992), pp. 277-279.

(5) Bonavetti, V. L.: Cementos con Filler Calcáreo - Mecanismo de Interacción y su Influencia sobre las Propiedades Resistentes. Tesis de Magister en Tecnología y Construcciones de Hormigón. 242 pp., 1998.

(6) $\mathrm{ACl}$ 225R-85. Guide to the Selection and use of Hydraulic Cements. ACl Manual of Concrete Practice. Part 1. Materials and General Properties of Concrete. p. 225 R-7. 1991.

(7) Mindess, S. y Young, J.: Concrete, p. 36, Prentice - Hall, inc. Englewood, Cliffs. New Jersey, 1981.

(8) Malhotra, M.: "Properties of Fresh and Hardened Concrete Incorporating Ground Granulated Blast Furnace Slag", Supplementary Cementing Materials for Concrete, p. 325, V. M. Malhotra, Canadá. Chapter 5, 1987.

(9) Menéndez, G.; Bonavetti, V. L. y Irassar, E. F.: "Strength development of ternary blended cement with limestone filler and blast-furnace slag", Cement and Concrete Composites, vol. 25, no 1 (2003), pp. 57-63.

(10) Powers, T. C.: "The non Evaporable Water Content of Hardened Portland Cement Paste", ASTM Bulletin, vol. 158 (1949), pp. 68-75.

(11) Montgomery, D. C.: Diseño y análisis de experimentos, Grupo Editorial Iberoamérica, México, 1998.

(12) Irassar, E. F.; Bonavetti, V. L.; Cabrera, O.; Donza, H. y Menéndez, G.: "Mechanical properties and durability of concrete made with Portland limestone cement", Three-Day International Symposium on Sustainable Development and Concrete Technology, San FrancisCo, USA. ACI Special Publication 202-27 (2001), pp. 431-450.

(13) Bombled, J. P.: "Rhéologie du béton frais: Influence de lájout de fillers aux ciments", Proc. $8^{\text {th }}$. International Congress on the Chemistry of Cement, Río de Janeiro, vol. 4 (1986), pp. 190-196.

(14) Zhang, C.; Wang, A.; Tang, M. y Liu, X.: "The filling role of pozzolanic material", Cement and Concrete Research, vol. 26, no 6 (1996), pp. 943-947.

(15) Soroka, I.: Portland cement paste and concrete, Chemical Publishing Co, Inc. New York. 1979.

(16) Bonavetti, V. L.; Rahhal, V. F.; Irassar, E. F.: "Evolución de la hidratación en cementos con adiciones", Materiales de Construcción, vol. 52, no 268 (2002), pp. 57-64.

(17) Metha, P. K. y Monteiro, P. J. M.: Concrete structure, properties and materials, Prentice Hall, New Jersey, 1993.

(18) Bonavetti, V. L.; Menéndez, G.; Donza, H. A.; Rahhal, V. F.; Irassar, E. F.: "Cementos compuestos elaborados con puzolana natural y escoria granulada de alto horno", Materiales de Construcción, vol. 56, no 283 (2006), pp. 25-36.

(19) Goldman, A. y Bentur, A.: "Effects of pozzolanic and non-reactive microfillers on the transition zone in high strength concretes, Interfaces in Cementitious Composites", Proc. № 18 RILEM International Conference (1993), pp. 53-61.

(20) Detwiler, R. J.; Krishnan, K. y Mehta, P. K.: "Effects of granulated blast furnace slag on the transition zone in concrete", Katharine and Bryant Mather International Conference, ACl SP-100, Detroit (1987), pp. 63-72.

(21) Bonavetti, V. L.; Donza, H.; Rahhal, V. L. e Irassar, E.: "Influence of initial curing on properties of concrete containing limestone blended cement", Cement and Concrete Research, vol. 30 (2000), pp. 703-708.

(22) Ramachandran, V. y Zhang, C.: "Influence of $\mathrm{CaCO}_{3}$ on hydration and microstructural characteristics of tricalcium silicate", I/ Cemento, vol. 83, no 3 (1986), pp. 129-152.

(23) $\mathrm{ACl}$ 233. Ground granulated blast-furnace slag as a cementitious constituent in concrete. ACI Manual of Concrete Practice. Part 1. Materials and General Properties of Concrete, 1998. 